\title{
AKUNTABILITAS PEMERINTAH TERHADAP PELAYANAN PUBLIK DI DESA BOLA BULU KECAMATAN PITU RIASE KABUPATEN SIDENRENG RAPPANG
}

\author{
Herman D. ${ }^{1}$, Ayu Angreani ${ }^{2}$ \\ Fakultas IImu Sosial dan IImu Politik, Universitas Muhammadiyah Sidenreng Rappang \\ e-mail: hermandema1010@gmail.com \\ ayuanggraeni43151085@gmail.com
}

\begin{abstract}
Abstrak
Penelitian ini bertujuan untuk mengetahui akuntabilitas pemerintah terhadap pelayanan publik di Desa Bola Bulu Kecamatan Pitu Riase Kabupaten Sidenreng Rappang. Populasi penelitian ini adalah 35 orang dan sampel sebanyak 35 orang. Teknik penarikan sampel yang digunakan yaitu Sampling Jenuh (sensus). Tipe penelitian ini adalah deskriptif kuantitatif. Teknik pengumpulan data adalah observasi, wawancara, penelitian pustaka dan kuesioner. Teknik analisis data menggunakan statistik. Hasil penelitian menunjukkan bahwa akuntabilitas pemerintah $60 \%$ kurang baik, meliputi hukum $57 \%$, kejujuran $66 \%$, manajerial $55 \%$, program $61 \%$, kebijakan $56 \%$, dan finansial $64 \%$. Pelayanan publik $65 \%$ baik, meliputi sederhana $58 \%$, jelas $58 \%$, keamanan $68 \%$, terbuka $73 \%$, efisien $66 \%$, ekonomis $67 \%$, dan keadilan $63 \%$. Hal ini menunjukkan akuntabilitas pemerintah terhadap pelayanan publik di Desa Bola Bulu Kecamatan Pitu Riase adalah 62\% dari $100 \%$ hasil yang diharapkan, dimana ini tergolong dalam kategori "baik".
\end{abstract}

Kata kunci : Akuntabilitas Pemerintah dan Pelayanan Publik

\begin{abstract}
This study aims to determine the government's accountability for public services in Bola Bulu Village, Pitu Riase District, Sidenreng Rappang Regency. The population of this study was 35 people and a sample of 35 people. The sampling technique used is a saturated sampling (census). This type of research is a quantitative descriptive. Data collection techniques are observation, interviews, library research, and questionnaires. Data analysis techniques use statistics. The results showed that government accountability was $60 \%$ less good, covering $57 \%$ law, $66 \%$ honesty, 55\% managerial, 61\% program, 56\% policy, and 64\% financial. While public services $65 \%$ are good, covering simple $58 \%$, clear $58 \%$, security $68 \%$, open $73 \%$, efficient $66 \%$, economical $67 \%$, and justice $63 \%$. This shows that the government's accountability for public services in Bola Bulu Village, Pitu Riase District is $62 \%$ of the $100 \%$ expected result, which is classified as "good".
\end{abstract}

Keywords: Government Accountability and Public Services

PRAJA| Volume 8| Nomor 2| Edisi Juni 2020 


\section{A. PENDAHULUAN}

Berdasarkan Undang-Undang Nomor 23 tahun 2014 tentang Pemerintahan Daerah, Desa sebagai kesatuan masyarakat hukum yang memiliki batas wilayah, yang berwenang untuk mengatur dan mengurus kepentingan masyarakat setempat berdasarkan asal-usul dan adat-istiadat setempat yang diakui dan dihormati dalam sistem pemerintahan Negara Kesatuan Republik Indonesia. Untuk dapat mengemban amanat Undang-Undang penyelenggaraan pemerintah daerah tersebut, maka pemerintah membutuhkan dukungan dari aparatur pemerintah daerah yang tangguh, profesional dan mampu bekerja secara akuntabel serta bersaing secara global. Perhatian yang besar terhadap desa didasarkan pada kenyataan bahwa desa merupakan tempat berdiamnya sebagian besar rakyat Indonesia. Kedudukan desa dan masyarakat desa merupakan dasar landasan kehidupan bangsa dan negara Indonesia. Desa sebagai kesatuan masyarakat hukum terkecil yang memiliki batas-batas wilayah yang berwenang untuk mengatur dan mengurus kepentingan masyarakatnya berdasarkan asal-usul dan adat-istiadat setempat yang diakui dan dihormati oleh Negara.

Akuntabilitas publik merupakan landasan utama proses penyelenggaraan pemerintahan yang baik. Karena itu aparatur pemerintah harus mempertanggung jawabkan seluruh aktivitas dan pelaksanaan kerjanya kepada publik. Dalam konteks organisasi pemerintahan sendiri, akuntabilitas publik merupakan pemberian informasi atas aktivitas dan kinerja pemerintah kepada pihak-pihak yang berkepentingan. Penekanan utama akuntabilitas publik adalah pemberian informasi kepada publik dan konstituen lainnya yang menjadi pemangku kepentingan (stakeholder). Akuntabilitas publik juga terkait dengan kewajiban untuk menjelaskan dan menjawab pertanyaan mengenai apa yang telah, sedang, dan direncanakan akan dilakukan organisasi sektor publik. (Mahmudi, 2002:9). Tanggungjawab masyarakat untuk melakukan kontrol terhadap lembaga pemerintah merupakan wujud dari bentuk partisipasi masyarakat. Hal ini amat penting memperoleh perhatian kita bersama, karena akuntabilitas itu sendiri tidak hanya diperlukan bagi pemerintah saja akan tetapi juga bagi masyarakat. Akuntabilitas bagi masyarakat seharusnya dibarengi dengan adanya sarana akses yang sama bagi seluruh masyarakat untuk melakukan kontrol terhadap pemerintah. Jika akses dan saluran ini diberikan oleh pemerintah, maka sarana tersebut bisa dimanfaaatkan untuk berperan serta dan melakukan kontrol. Akses dan saluran ini perlu diadakan oleh pemerintah agar semua kelompok masyarakat mempunyai hak dan kesempatan yang sama dalam memanfaatkan saluran tersebut. Akuntabilitas diartikan bahwa suatu instansi pemerintah telah menetapkan dan mempunyai visi, misi, tujuan dan sasaran yang jelas terhadap program kerja yang telah, sedang, atau yang akan dijalankan. Dengan akuntabilitas juga akan dapat diukur bagaimana mereka menyelenggarakan dan mempertahankan (memegang) tanggungjawab mereka terhadap pencapaian hasil.

Meluasnya praktik-praktik KKN (korupsi, kolusi dan nepotisme) dalam kehidupan birokrasi publik semakin mencoreng pemikiran masyarakat terhadap birokrasi publik. Disadari bahwa kondisi penyelenggaraan pelayanan publik masih dihadapkan pada sistem pemerintahahan yang belum efektif dan efisien serta kualitas sumber daya manusia aparatur yang belum memadai. Hal ini, terlihat dari masih banyaknya keluhan dan pengaduan dari masyarakat baik secara langsung maupun melalui media massa, seperti: prosedur yang berbelit-belit, tidak ada kepastian jangka waktu penyelesaian, biaya yang harus dikeluarkan, persyaratan yang tidak transparan, sikap petugas yang kurang responsive dan lain-lain, sehingga menimbulkan citra yang kurang baik terhadap citra pemerintah.

Banyaknya keluhan dan pengaduan dari masyarakat terhadap pelayanan dari pemerintah baik yang secara langsung maupun melalui media massa menimbulkan citra yang buruk kepada pemerintah. Padahal disisi lainnya masyarakat merindukan pelayanan publik yang baik dengan adanya keseimbangan antara kekuasaan (power) yang dimiliki dengan tanggung jawab yang 
mesti diberikan kepada masyarakat yang dilayani. Pegawai sebagai aparat birokrasi selain sebagai aparatur negara dan abdi negara, memiliki peran sebagai abdi masyarakat. Sehingga kepada kepentingan masyarakatlah aparat birokrasi harusnya mengabdikan diri. Aparat birokrasi diharapkan memiliki jiwa pengabdian dan pelayanan kepada masyarakat, Untuk mengatasi kondisi tersebut perlu dilakukan upaya akuntabilitas pemerintahan terhadap perbaikan kualitas penyelenggaraan pelayanan publik yang berkesinambungan demi mewujudkan pelayanan publik yang prima sebab pelayanan publik merupakan salah satu fungsi utama pemerintah yang wajib diberikan sebaik-baiknya oleh penyelenggaraan negara.

Salah satu upaya pemerintah adalah dengan melakukan penerapan prinsip-prinsip good governance (pemerintahan yang baik), yang diharapkan dapat memenuhi pelayanan yang prima terhadap masyarakat ataupun publik. Untuk itu, aparatur negara diharapkan semakin efisien dan efektif melaksanakan tugas dan tanggung jawabnya dalam menyelenggarakan pemerintahan, pembangunan, dan pengayoman kepada masyarakat (public) untuk mewujudkan terselenggaranya pemerintahan yang baik (good governance), serta memberikan pelayanan prima kepada masyarakat. Dan diharapkan melalui penerapan tata pemerintahan yang baik dapat mengembalikan dan membangun kembali kepercayaan masyarakat kepada penyelenggara pemerintahan.

Berdasarkan uraian di atas, maka peneliti tertarik meneliti tentang Akuntabilitas Pemerintah terhadap Pelayanan Publik di Desa Bola Bulu Kecamatan Pitu Riase Kabupaten Sidenreng Rappang dengan tujuan untuk mengetahui akuntabilitas pemerintah terhadap pelayanan publik di Desa Bola Bulu Kecamatan Pitu Riase Kabupaten Sidenreng Rappang.

Menurut Ndraha (Zainuddin, 2017:343) konsep akuntabilitas berawal dari konsep pertanggung jawaban, konsep pertanggung jawaban sendiri dapat dijelaskan dari adanya wewenang. Wewenang disini berarti kekuasaan yang sah. Menurut Weber (Zainuddin, 2017:343) ada tiga macam tipe ideal wewenang, pertama: wewenang tradisional, kedua: wewenang karismatik, ketiga: wewenang legal rational. Yang ketiga inilah menjadi basis wewenang pemerintah. Dalam perkembangannya, muncul konsep baru tentang wewenang yang dikembangkan oleh Bernard yang bermuara pada prinsip bahwa penggunaan wewenang harus dapat dipertanggung jawabkan.

Darwin (Zainuddin, 2017:344) membedakan konsep pertanggung jawaban menjadi tiga. Pertama, akuntabilitas (accountability), kedua, responsibilitas (responsibility) dan ketiga, responsivitas (responsiveness). Sebelum menjelaskan tentang pertanggung jawaban sebagai akuntabilitas (accountability), dijelaskan lebih dahulu pertanggung jawaban sebagai responsibilitas (responsibility) dan sebagai responsivitas (responsiveness).

Pasal 7 Undang-Undang Nomor 28 Tahun 1999 (Zainuddin, 2017:349) menjelaskan bahwa yang dimaksud asas akuntabilitas adalah asas yang menentukan bahwa setiap kegiatan dan hasil dari kegiatan penyelenggaraan negara harus dapat dipertanggung jawabkan kepada masyarakat/rakyat sebagai pemegang kedaulatan tertinggi negara sesuai dengan ketentuan peraturan perUndang-Undangan yang berlaku. Dimensi akuntabilitas ada lima, yaitu (Syahrudin dalam Zainuddin, 2017:349):

a. Akuntabilitas hukum dan kejujuran. Akuntabilitas hukum adalah kepatuhan terhadap hukum yang diisyaratkan dalam organisasi, sedangkan akuntabilitas kejujuran adalah penghindaran penyalahgunaan jabatan, korupsi dan kolusi.

b. Akuntabilitas manajerial, diartikan sebagai akuntabilitas kinerja adalah pertanggung jawaban untuk melakukan pengelolaan organisasi secara efektif dan efisien.

c. Akuntabilitas program, bahwa programprogram organisasi hendaknya merupakan program yang bermutu dan mendukung strategi dalam pencapaian visi, misi dan tujuan organisasi.

d. Akuntabilitas kebijakan. Lembaga publik hendaknya dapat mempertanggung jawabkan kebijakan yang telah ditetapkan dengan mempertimbangkan dampak dimasa depan.

e. Akuntabilitas finansial, akuntabilitas ini merupakan pertanggung jawaban 
lembaga-lembaga publik untuk menggunakan dana publik (public money) secara ekonomis, efisien dan efektif, tidak ada pemborosan dan kebocoran dana serta korupsi. Akuntabilitas finansial ini sangat penting karena menjadi sorotan utama masyarakat. Akuntabilitas ini mengharuskan lembaga-lembaga publik untuk membuat laporan keuangan untuk menggambarkan kinerja finansial organisasi kepada pihak luar.

Lembaga Administrasi Negara (LAN) yang seperti dikutip Badan Pengawas Keuangan dan Pembangunan (BPKP) dalam bukunya Akuntabilitas dan Good Governance (2000:24), membedakan akuntabilitas dalam tiga macam akuntabilitas, yaitu:

1. Akuntabilitas Keuangan. Akuntabilitas keuangan merupakan pertanggungjawaban mengenai integritas keuangan, pengungkapan dan ketaatan terhadap peraturan perundangundangan. Sasarannya adalah laporan keuangan yang mencakup penerimaan, penyimpanan dan pengeluaran keuangan instansi pemerintah. Komponen pembentuk akuntabilitas keuangan terdiri atas:

a. Integritas Keuangan Menurut Kamus Besar Bahasa Indonesia, integritas berarti kejujuran, keterpaduan, kebulatan dan keutuhan. Dengan kata lain, integritas keuangan mencerminkan kejujuran penyajian. Agar laporan keuangan dapat diandalkan informasi yang terkandung didalamnya harus menggambarkan secara jujur transaksi serta peristiwa lainnya yang seharusnya disajikan atau yang secara wajar dapat diharapkan untuk disajikan.

b. Pengungkapan Konsep pengungkapan mewajibkan agar laporan keuangan didesain dan disajikan sebagai kumpulan gambaran atau kenyataan dari kejadian ekonomi yang mempengaruhi instansi pemerintahan untuk suatu periode dan berisi cukup informasi.

c. Ketaatan terhadap Peraturan Perundang-undangan Akuntansi dan pelaporan keuangan pemerintah harus menunjukkan ketaatan terhadap peraturan perundang-undangan yang berkaitan dengan pelaksanaan akuntansi pemerintahan. Apabila terdapat pertentangan antara standar akuntansi keuangan pemerintah dengan peraturan perundangundangan yang lebih tinggi, maka yang digunakan adalah peraturan perundang-undangan yang lebih tinggi.

2. Akuntabilitas Manfaat. Akuntabilitas manfaat pada dasarnya memberi perhatian pada hasil-hasil dari kegiatan pemerintahan. Hasil kegiatannya terfokus pada efektivitas, tidak sekedar kepatuhan terhadap prosedur. Bukan hanya output, tapi sampai outcome. Outcome adalah dampak suatu program atau kegiatan terhadap masyarakat. Outcome lebih tinggi nilainya daripada output, karena output hanya mengukur dari hasil tanpa mengukur dampaknya terhadap masyarakat, sedangkan outcome mengukur output dan dampak yang dihasilkan. Pengukuran outcome memiliki dua peran yaitu restopektif dan prospektif. Peran restopektif terkait dengan penilaian kinerja masa lalu, sedangkan peran prospektif terkait dengan perencanaan kinerja di masa yang akan datang.

3. Akuntabilitas Prosedural. Akuntabilitas yang memfokuskan kepada informasi mengenai tingkat kesejahteraan sosial. Diperlukan etika dan moral yang tinggi serta dampak positif pada kondisi sosial masyarakat. Akuntabilitas prosedural yaitu merupakan pertanggungjawaban mengenai aspek suatu penetapan dan pelaksanaan suatu kebijakan yang mempertimbangkan masalah moral, etika, kepastian hukum dan ketaatan pada keputusan politik untuk mendukung pencapaian tujuan akhir yang telah ditetapkan.

Pelayanan publik adalah kegiatan atau rangkaian kegiatan dalam rangka pemenuhan kebutuhan pelayanan sesuai dengan peraturan perundang-undangan bagi setiap warga negara dan penduduk atas barang, jasa, dan atau pelayanan administratif yang disediakan oleh penyelenggara pelayanan publik.

Penyelenggara pelayanan publik adalah setiap institusi penyelenggara negara, korporasi, lembaga indepenen yang dibentuk berdasarkan undang-undang untuk kegiatan pelayanan publik, dan badan hukum lain 
yang dibentuk semata-mata untuk kegatan pelayanan publik. Hilangnya kepercayaan masyarakat terhadap penyelenggara pelayanan publik akan berakibat rusaknya tatanan hukum dan aturan yang menjadi prasyarat bagi suatu kedaulatan negara. Peraturan dan keteraturan (rule and order) menjadi modal dasar bagi terbangunnya demokrasi dan keadilan dalam masyarakat.

Mahmudi (Kamaruddin, 2016:76) mengemukakan bahwa pelayanan publik adalah segala kegiatan pelayanan yang dilaksanakan oleh penyelenggara pelayanan publik sebagai para pemenuhan kebutuhan publik dan pelaksanaan ketentuan peraturan perundang-undangan. Dalam hal ini, yang dimaksud penyelenggara pelayanan publik adalah instansi pemerintah yang meliputi:

a. Satuan kerja/satuan organisasi kementerian;

b. Departemen;

c. Lembaga pemerintah non departemen;

d. Kesekretariatan lembaga tertinggi dan tinggi negara, misalnya Sekretariat Dewan (SetWan), Sekretariat Negara (SetNeg), dan sebagainya;

e. Badan Usaha Milik Negara (BUMN);

f. Badan Hukum Milik Negara (BHMN);

g. Badan Usaha Milik Daerah (BUMD);

h. Instansi pemerintah lainnya, baik pusat maupun daerah termasuk dinas-dinas dan badan.

Peraturan Menteri Pendayagunaan Aparatur Negara dan Reformasi Birokrasi Nomor 36 Tahun 2012 tentang Petunjuk Teknis Penyusunan, Penetapan, dan Penerapan Standar Pelayanan, Bab II Point A berbunyi bahwa "standar pelayanan adalah tolak ukur yang dipergunakan sebagai pedoman penyelenggaraan pelayanan dan acuan penilaian kualitas pelayanan sebagai kewajiban dan janji penyelenggara kepada masyarakat dalam rangka pelayanan yang berkualitas, cepat, mudah, terjangkau dan terukur". Kamaruddin (2016:78)

Pelayanan publik yang diselenggarakan oleh birokasi publik adalah merupakan salah satu perwujudan dari fungsi aparatur negara sebagai abdi negara masyarakat disamping sebagai abdi negara (Saefullah dalam Kamaruddin, 2016:95). Pelayanan publik tersebut dimaksudkan untuk mensejahterakan masyarakat dari suatu negara kesejahteraan (welfare state).
Pelayanan umum oleh Lembaga Administrasi Negara diartikan sebagai segala bentuk kegiatan pelayanan umum yang dilaksanakan oleh Instansi Pemerintah di Pusat, di Daerah dan di lingkungan Badan Usaha Milik Negara/Daerah dalam bentuk barang dan atau jasa baik dalam rangka upaya kebutuhan masyarakat maupun dalam rangka pelaksanaan ketentuan peraturan perundang-undangan.

Zeithhaml, dkk (Kamaruddin, 2016:105) menawarkan indikator untuk mengetahui kualitas pelayanan yang dirasakan secara nyata oleh konsumen yaitu:

a. Tangibles yaitu kualitas pelayanan yang berupa sarana fisik perkantoran, komputerisasi administrasi, ruang tunggu, tempat informasi.

b. Reliability yaitu kemampuan atau keandalan untuk menyediakan pelayanan yang terpercaya.

c. Responsiveness yaitu kesanggupan untuk membantu dan menyediakan pelayanan secara cepat dan tepat, serta tanggap terhadap keinginan konsumen.

d. Assurance yaitu kemampuan dan keramahan serta sopan santun pegawai dalam meyakinkan kepercayaan konsumen.

e. Emphaty yaitu sikap tegas tetapi penuh perhatian dari pegawai terhadap konsumen.

Dalam Lahibu Tuwu (Kamaruddin, 2016:146), mengemukakan bahwa kualitas layanan sumber daya manusia yaitu kemampuan dalam menghasilkan sumber daya manusia yang mampu mengembangkan potensi diri dan organisasinya dalam melaksanakan tugas untuk mencapai tujuan. Indikator mengacu kepada tujuh bentuk pelayanan publik dari Yoga, yaitu:

a) Sederhana yaitu penerapan pelayanan yang sesuai dengan prosedur/tata cara pelayanan yang diselenggarakan secara mudah, lancar, cepat, tidak berbelit-belit, mudah dipahami, dan mudah dilaksanakan oleh publik yang menerima pelayanan.

b) Jelas yaitu pelayanan yang mencakup prosedur/tata cara pelayanan, persyaratan teknis maupun administratif, unit kerja dan pejabat yang berwewenang dan 
bertanggung jawab serta sesuai jadwal waktu penyelesaian pelayanan.

c) Keamanan yaitu proses hasil pelayanan yang memberikan rasa aman dan memiliki kepastian hukum bagi publik.

d) Terbuka yaitu pelayanan yang sesuai dengan prosedur/tata cara, persyaratan, rincian tarif/biaya dan proses pelayanan yang ditransformasikan secara terbuka agar mudah diketahui oleh publik, diminta maupun tidak diminta.

e) Efisien yaitu pelayanan yang dibatasi pada hal-hal yang berkaitan langsung dengan pencapaian sasaran pelayanan dengan memperhatikan keterpaduan antara persyaratan dengan pelayanan yang diberikan.

f) Ekonomis yaitu pengenaan biaya pelayanan yang ditetapkan secara wajar dengan memperhatikan nilai layanan yang diberikan, kondisi dan kemampuan publik serta sesuai dengan ketentuan peraturan perundang-undangan yang berlaku.

g) Keadilan yaitu pelaksanaan pelayanan publik yang dapat diselesaikan dalam kurun waktu yang telah ditentukan dan tidak membeda-bedakan antara publik yang satu dengan publik yang lainnya sebagai pengguna layanan.

Istilah desa berasal dari bahasa india swadesi yang berarti tempat asal, tempat tinggal, negeri asal atau tanah leluhur yang merajuk pada suatu kesatuan hidup dengan kesatuan hidup dengan kesatuan norma serta memiliki batas yang jelas. Istilah desa dan pedesaan sering dikaitkan dengan pengertian rural dan village yang dibandingkan dengan kota (city/town) dan perkotaan (urban). Konsep perdesaan dan perkotaan mengacu kepada karakteristtik masyarakat, sedangkan desa dan kota merajuk pada suatu wilayah administrasi atau tutorial, dalam hal ini perdesaan mencakup beberapa desa. Definisi tentang desa sendiri sampai sekarang belum dikaji karena batasannya menjadi perdebatan panjang di kalangan para ahli. Desa dibentuk berdasarkan kebutuhan masyarakat di daerah sutu dengan daerah lain yang berbeda kulturnya. Beberapa para ahli atau pakar mengemukakan pendapatnya dari tinjauannya masing-masing. (Nurman, 2015:226)
Dalam Wasistiono dan Tahir (2006) yang memandang desa dari aspek geografis mendefinisikan desa sebagai "suatu hasil perwujudan antra kegiatan sekelompok orang manusia dengan lingkungannya. Hasil dari perpaduan itu ialah suatu wujud atau penampakan di muka bumi yang ditimbulkan oleh unsur-unsur fisiografi, sosial ekonomi, politisi, dan kultural yang saling berinteraksi antar unsur tersebut dan juga dalam hubungannya dengan daerah lain".

$$
\text { Nurcholis (Nurman, 2015:227) }
$$

menyatakan desa merupakan satuan pemerintahan yang diberi hak otonomi adat sehingga merupakan badan hukum yang berhak mengatur dan mengurus urusan masyarakat setempat berdasarkan asal usulnya. Definisi yang disampaikan lebih menekankan pada aspek hukum pedesaan dan hak otonomu desa untuk mengatur kepemerintahan desa itu sendiri secara mandiri.

Secara etimologis kata pemerintahan berasal dari kata pemerintahan, kata pemerintah sendiri berasal dari kata Perintah yang berarti menyuruh melakukan suatu pekerjaan. Namun tinjauan asal kata pemerintah sebenarnya berasal dari kata dalam bahasa inggris government yang diterjemahkan sebagai pemerintah dan pemerintahan dalam banyak tulisan. Namun, ada juga yang berpendapat bahwa "government" tidak selalu memiliki makna pemerintahan karena Samuel Edward Finer (Syafiie, 2003:13) mengartikan "government" sebagai public servant yakni pelayanan.

Suatu pemerintahan hadir karena adanya suatu komitmen bersama yang terjadi antara pemerintah dengan rakyatnya sebagai pihak yang diperintah dalam suatu posisi atau peran, yang mana komitmen tersebut hanya dapat dipegang apabila rakyat dapat merasa bahwa pemerintah itu memang diperlukan untuk melindungi, memberdayakan dan menyejahterakan rakyat. Tugas pemerintahan adalah untuk melayani dan mengatur masyarakat. Tugas pelayanan lebih menekankan upaya mendahulukan kepentingan umum, mempermudah urusan publik dan memberikan kepuasan kepada publik, sedangkan tugas mengatur lebih menekankan kekuasaan power yang melekat 
pada posisi jabatan birokrasi (Nurman, 2015:57).

Susunan pemerintahan desa terdiri atas Pemerintah Desa (Pemdes) dan Badan Perwakilan Desa (BPD). Pemdes dipimpin oleh Kepala Desa dan dibantu perangkat desa yang bertanggung jawab langsung kepada Kepala Desa. BPD adalah badan perwakilan yang terdiri atas pemuka masyarakat yang ada di desa dan berfungsi mengayomi adat-istiadat, membuat peraturan desa (Perdes), menampung dan menyalurkan aspirasi masyarakat serta melakukan pengawasan terhadap penyelenggaraan pemerintahan desa. (Nurman, 2015:237)

Kepala Desa sebagai Kepala Pemerintahan Desa yang berada dibawah dan bertanggung jawab kepada Camat. Berdasarkan UU Nomor 6 Tahun 2014 tentang Desa, pada Bagian Kedua Pasal 26 disebutkan bahwa Kepala Desa bertugas menyelenggarakan Pemerintahan Desa, melaksanakan Pembangunan Desa, Pembinaan Kemasyarakatan Desa, dan Pemberdayaan Masyarakat Desa. Dalam melaksanakan tugas sebagaimana tersebut, menurut Undang-Undang Nomor 6 Tahun 2014 tentang Desa.

\section{B. METODE PENELITIAN}

Dalam penelitian ini variabel $X$ adalah akuntabilitas pemerintah dan variabel $Y$ adalah pelayanan publik. Desain penelitian yang digunakan adalah deskriptif dengan menggunakan pendekatan Kuantitatif yaitu yang bertujuan untuk menggambarkan permasalahan secara sistemis, faktual dan aktual yang terjadi di lokasi penelitian yaitu menjelaskan tentang akuntabilitas pemerintah terhadap pelayanan publik di Desa Bola Bulu Kecamatan Pitu Riase Kabupaten Sidenreng Rappang.

Populasi dalam penelitian ini adalah pelayanan yang berlangsung selama bulan Januari 2019 di Kantor Desa Bola Bulu Kecamatan Pitu Riase sebanyak 35 orang (Sumber: Data Pelayanan, Januari 2019). Teknik penarikan sampel yang digunakan dalam penelitian ini adalah Sampling Jenuh (Sensus). Sampling jenuh (Jamaluddin, 2015:142) yaitu teknik penentuan sampel bila semua anggota populasi digunakan sebagai sampel. Dengan demikian, maka sampel pada penelitian ini berjumlah 35 orang. Informan dalam penelitian ini yaitu Tokoh Masyarakat di Desa Bola Bulu Kecamatan Pitu Riase Kabupaten Sidenreng Rappang. Teknik pengumpulan data yang digunakan adalah observasi, wawancara, penelitian pustaka, kuesioner.

Dalam penelitian kuantitatif, analisis data merupakan kegiatan setelah data dari responden atau sumber data lain terkumpul. Data hasil penelitian dianalisis dengan alat statistik, berupa (Kamaruddin, 2016:180): analisis statistik deskriptif, yaitu digunakan untuk menganalisis data dengan cara mendeskripsikan atau menggambarkan data yang terkumpul sebagaimana adanya tanpa bermaksud untuk membuat kesimpulan yang berlaku untuk umum atau generalisasi (Sugiyono, 2009:169). Analisis statistik deskriptif digunakan untuk menjelaskan karakteristik responden meliputi: tingkat pendidikan, usia, dan jenis kelamin. Selain itu analisis statistik deskriptif juga digunakan untuk menjelaskan tanggapan responden terhadap variabel penelitian. (Kamaruddin, 2016:180) Langkah terakhir adalah mendiskripsikan hasil analisis data sehingga pada akhirnya dapat ditarik sebuah kesimpulan. Data yang diperoleh melalui kuesioner dianalisis dengan menggunakan model skala likert yang telah dimodifikasi oleh penulis (Kamaruddin, 2016:183).

\section{HASIL DAN PEMBAHASAN}

Desa Bola Bulu merupakan salah satu dari 12 Desa/Kelurahan yang ada di Kecamatan Pitu Riase dengan luas wilayah $19,30 \mathrm{~km}^{2}$, terdiri dari 6 Dusun, 8 RW dan 16 RT. Desa Bola Bulu terletak .... km dari Ibukota Kabupaten Sidenreng Rappang, atau $15 \mathrm{~km}$ dari Ibukota Kecamatan Pitu Riase, dengan batas wilayah sebagai berikut:

$\begin{array}{ll}\text { Sebelah Utara } & \text { : Desa Botto } \\ \text { Sebelah Selatan } & \text { : Desa Bila }\end{array}$

Sebelah Barat : Desa Bulucenrana Kecamatan Pitu Riawa

Sebelah Timur : Desa Salobukkang Kecamatan Dua Pitue

1. Akuntabilitas Pemerintah (X)

a. Hukum, rata-rata skor 2.85, rata-rata persentase $57 \%$ kategori kurang baik.

b. Kejujuran, rata-rata skor 3.28, rata-rata persentase 66 kategori baik. 
c. Manajerial, rata-rata skor 2.74 , rata-rata persentase $55 \%$ kategori kurang baik.

d. Program, rata-rata skor 3.05 , rata-rata persentase $61 \%$ kategori baik.

e. Kebijakan, rata-rata skor 2.82, rata-rata persentase $56 \%$ kategori kurang baik.

f. Finansial, rata-rata skor 3.2, rata-rata persentase $64 \%$ kategori baik.

Dengan mengakumulasi hasil rata-rata persentase dari 6 indikator pertanyaan pada variabel akuntabilitas pemerintah di atas, maka didapatkan hasil rata-rata persentase $60 \%$. Adapun keseluruhan frekuensi adalah sebesar 629.

2. Pelayanan Publik (Y)

a. Sederhana, rata-rata skor 2.91, ratarata persentase $58 \%$ kategori kurang baik.

b. Jelas, rata-rata skor 2.91, rata-rata persentase $58 \%$ kategori kurang baik.

c. Keamanan, rata-rata skor 3.42 , ratarata persentase $68 \%$ kategori baik.

d. Terbuka, rata-rata skor 3.65 , rata-rata persentase $73 \%$ kategori baik.

e. Efisien, rata-rata skor 3.31, rata-rata persentase $66 \%$ kategori baik.

f. Ekonomis, rata-rata skor 3.37, rata-rata persentase $67 \%$ kategori baik.

g. Keadilan, rata-rata skor 3.17, rata-rata persentase $63 \%$ kategori baik.

Dengan mengakumulasi hasil rata-rata persentase dari 7 indikator pertanyaan pada variabel pelayanan publik di atas, maka didapatkan hasil rata-rata persentase $65 \%$. Adapun keseluruhan frekuensi adalah sebesar 797.

Berdasarkan penelitian terdahulu dengan judul Akuntabilitas Pemerintah terhadap Pelayanan Masyarakat di Kecamatan Dua Pitue Kabupaten Sidenreng Rappang", hasil penelitian menunjukkan bahwa akuntabilitas pemerintah dalam pelayanan masyarakat di Kecamatan Dua pitue tergolong tinggi (Andi Jerni, 2013:3940). Penelitian terdahulu tidak sejalan dengan penelitian saat ini, dimana pada penelitian ini akuntabilitas pemerintah dinilai $60 \%$ kurang baik, meskipun pelayanan publik dinilai $65 \%$ baik.

Terdapat beberapa indikator yang perlu ditinjau kembali untuk dilakukan koreksian agar terjadi perbaikan akuntabilitas pemerintah terhadap pelayanan publik. Misalnya pada variabel akuntabilitas pemerintah yaitu indikator hukum, manajerial dan kebijakan. Artinya aparat Desa Bola Bulu masih kurang terbuka dalam penyampaian, apakah penyampaian kelengkapan berkas, penyampaian data-data yang dibutuhkan masyarakat, dan sebagainya. Aparat belum sepenuhnya melaksanakan tanggung jawabnya, contoh pada saat masih jam pelayanan, ada masyarakat yang membutuhkan aparat atau pegawai di Kantor Desa untuk dibuatkan surat pengantar, namun yang dibutuhkan sedang berada di luar dengan alasan yang tidak jelas. Hal yang semacam ini perlu dilakukan perbaikan, mengutamakan kepentingan umum dari pada kepentingan pribadi. Demi menciptakan akuntabilitas pelayanan publik yang sesuai dengan harapan masyarakat.

\section{KESIMPULAN}

Berdasarkan rekapitulasi akhir akuntabilitas pemerintah $60 \%$ kurang baik, meliputi hukum $57 \%$ kurang baik, kejujuran $66 \%$ baik, manajerial $55 \%$ kurang baik, program $61 \%$ baik, kebijakan $56 \%$ kurang baik, dan finansial $64 \%$ baik. Sedangkan pelayanan publik $65 \%$ baik, meliputi sederhana $58 \%$ kurang baik, jelas $58 \%$ kurang baik, keamanan $68 \%$ baik, terbuka $73 \%$ baik, efisien $66 \%$ baik, ekonomis $67 \%$ baik, dan keadilan $63 \%$ baik. Hal ini menunjukkan bahwa Akuntabilitas Pemerintah terhadap Pelayanan Publik di Desa Bola Bulu Kecamatan Pitu Riase adalah $62 \%$ dari $100 \%$ hasil yang diharapkan, dimana ini tergolong dalam kategori "baik".

\section{E. REFERENSI}

Hasbar, Mustafa. 2014. Menguak Perilaku Organisasi Sektor Publik Antara Teori dan Aplikasi. Ombak. Yogyakarta.

Jamaluddin, Ahmad. 2015. Metode Penelitian Admistrasi Publik. Gava Media. Yogyakarta.

Jerni, Andi. 2013. Akuntabilitas Pemerintah dalam

Pelayanan

Masyarakat di Kecamatan Dua Pitue Kabupaten Sidenreng Rappang. STISIP Muhammadiyah Sidenreng Rappang 
Lahibu, Tuwu. 2012. Disertasi. Pengaruh Gaya Kepemimpinan, Pengembangan Karir, Motivasi Kerja Terhadap Kinerja dan Kualitas Layanan Sumber Daya Manusia pada Pemerintah Daerah Kabupaten Buton. Program Pascasarjana UMI. Makassar

Lembaga Administrasi Negara dan Badan Pengawas Keuangan dan Pembangunan. 2000. Akuntabilitas, dan Good Governance. Lembaga Administrasi Negara dan Badan Pengawas Keuangan dan Pembangunan. Jakarta.

Mahmudi. 2002. Laporan Keuangan Sektor Publik Untuk Transparansi dan Akuntabilitas Publik. JPAI. Yogyakarta.

2010. Manajemen Kinerja Sektor Publik. Edisi Kedua. UPP STIM YKPN. Yogyakarta.

Mustafa, Delly. 2012. Perilaku Birokrasi: Diantara Pelayan dan Dilayani. Fahmis Pustaka. Makassar.

Nurcholis, Hanif. 2011. Pertumbuhan dan Penyelenggaraan

Pemerintahan

Desa. Erlangga. Jakarta.

Nurman. 2015. Strategi Pembangunan Daerah. Cetakan Ke-1. Rajawali Pers. Jakarta.

Rasyid. 2000. Makna Pemerintahan. Mutiara Sumber Widya. Jakarta.

Rosjidi. 2001. Akuntansi Sektor Publik Pemerintah: Kerangka, Standar dan Metode. Aksara Satu. Surabaya.

Sellang, Kamaruddin. 2016. Administrasi dan Pelayanan Publik, Antara Teori dan Aplikasi. Penerbit Ombak. Yogyakarta.
Sugiyono. 2009. Metode Penelitian Administrasi. Alfabeta. Bandung.

2013. Metode Penelitian Kuantitatif Kualitatif dan $R \& D$. Alfabeta. Bandung.

Syafiie, Inu Kencana. 2003. Sistem Administrasi Negara. Gajah Mada. Yogyakarta.

Wasistiono, Sadu. 2003. Kapita Selekta Manajemen Pemerintahan Daerah. Fokus Media. Bandung.

Wasistiono dan Tahir. 2006. Prospek Pengembangan Desa. Fokus Media. Bandung.

Widodo, Joko. 2001. Good Governance: Akuntabilitas dan Kontrol Birokrasi. Insan Cendikiawan. Surabaya.

Zainuddin. 2017. Teori-teori Mutakhir dalam Perspektif IImu Administrasi Publik: Inspirator Teori Birokrasi Transformasional. Phinatama Media.

Dokumen-dokumen: Makassar.

Keputusan Menteri Pendayagunaan Aparatur Negara Nomor: 63/KEP/M.PAN/7/2003 Tentang Pedoman Umum Penyelenggaraan Pelayanan Publik.

Peraturan Menteri Pendayagunaan Aparatur Negara dan Reformasi Birokrasi Nomor 36 Tahun 2012 tentang Petunjuk Teknis Penyusunan, Penetapan, dan Penerapan Standar Pelayanan.

Undang-Undang Nomor 6 Tahun 2014 tentang Desa.

Undang-Undang Nomor 23 Tahun 2014 tentang Pemerintahan Daerah. 